\title{
Anti-adipogenic and anti-obesity activities of purpurin in 3T3-L1 preadipocyte cells and in mice fed a high-fat diet
}

\author{
Woo Nam', Seok Hyun Nam, Sung Phil Kim², ${ }^{2,3^{*}}$ Carol Levin ${ }^{4}$ and Mendel Friedman ${ }^{4^{*}}$ (D
}

\begin{abstract}
Background: The body responds to overnutrition by converting stem cells to adipocytes. In vitro and in vivo studies have shown polyphenols and other natural compounds to be anti-adipogenic, presumably due in part to their antioxidant properties. Purpurin is a highly antioxidative anthraquinone and previous studies on anthraquinones have reported numerous biological activities in cells and animals. Anthraquinones have also been used to stimulate osteoblast differentiation, an inversely-related process to that of adipocyte differentiation. We propose that due to its high antioxidative properties, purpurin administration might attenuate adipogenesis in cells and in mice.
\end{abstract}

Methods: Our study will test the effect purpurin has on adipogenesis using both in vitro and in vivo models. The in vitro model consists of tracking with various biomarkers, the differentiation of pre-adipocyte to adipocytes in cell culture. The compound will then be tested in mice fed a high-fat diet. Murine 3T3-L1 preadipocyte cells were stimulated to differentiate in the presence or absence of purpurin. The following cellular parameters were measured: intracellular reactive oxygen species (ROS), membrane potential of the mitochondria, ATP production, activation of AMPK (adenosine 5'-monophosphate-activated protein kinase), insulin-induced lipid accumulation, triglyceride accumulation, and expression of PPARY (peroxisome proliferator activated receptor- $\gamma$ ) and C/EBPa (CCAAT enhancer binding protein a). In vivo, mice were fed high fat diets supplemented with various levels of purpurin. Data collected from the animals included anthropometric data, glucose tolerance test results, and postmortem plasma glucose, lipid levels, and organ examinations.

Results: The administration of purpurin at 50 and $100 \mu \mathrm{M}$ in 3T3-L1 cells, and at 40 and $80 \mathrm{mg} / \mathrm{kg}$ in mice proved to be a sensitive range: the lower concentrations affected several measured parameters, whereas at the higher doses purpurin consistently mitigated biomarkers associated with adipogenesis, and weight gain in mice. Purpurin appears to be an effective antiadipogenic compound.

Conclusion: The anthraquinone purpurin has potent in vitro anti-adipogenic effects in cells and in vivo anti-obesity effects in mice consuming a high-fat diet. Differentiation of 3T3-L1 cells was dose-dependently inhibited by purpurin, apparently by AMPK activation. Mice on a high-fat diet experienced a dose-dependent reduction in induced weight gain of up to $55 \%$.

Keywords: Adipogenesis, Anthraquinone, Antioxidant, Cell differentiation, Lipogenic diet, Madder, Mitochondria, Obesity, Rubia cordifolia

\footnotetext{
* Correspondence: ksp1108@ajou.ac.kr; mendel.friedman@ars.usda.gov

${ }^{2}$ Research Institute of Basic Science, Ajou University, Suwon 16499, Republic

of Korea

${ }^{4}$ Western Regional Research Center, Agricultural Research Service, U.S.

Department of Agriculture, Albany, California 94710, USA

Full list of author information is available at the end of the article
}

(c) The Author(s). 2019 Open Access This article is distributed under the terms of the Creative Commons Attribution 4.0 International License (http://creativecommons.org/licenses/by/4.0/), which permits unrestricted use, distribution, and

reproduction in any medium, provided you give appropriate credit to the original author(s) and the source, provide a link to the Creative Commons license, and indicate if changes were made. The Creative Commons Public Domain Dedication waiver (http://creativecommons.org/publicdomain/zero/1.0/) applies to the data made available in this article, unless otherwise stated. 


\section{Background}

Anthraquinones are aromatic compounds with a 9,10dioxoanthracene core substituted in the two benzene rings with phenolic $\mathrm{OH}$ and aliphatic groups. Anthraquinones have numerous reported biological activities, reviewed in Li and Jiang [1]. Purpurin, 1,2,4-trihydroxy anthraquinone (Fig. 1), is an alizarin-type anthraquinone with particularly high anti-oxidative activity $[1,2]$. Purpurin, and the related anthraquinone alizarin, are present as glycosides in the roots of the madder plant, the common name for both Rubia tinctorum L. and Rubia cordifolia [3]. These anthraquinones are responsible for the ancient natural pigments extracted from the madder plant used to dye textiles and color paints [4]. Rubia cordifolia contains primarily the purpurin glycoside, whereas Rubia tinctorum L. contains primarily the alizarin glycoside [3]. While not eaten for nourishment, the madder root has been used as a food colorant [5], and in traditional and conventional medicines to treat various aliments [6-8].

Purified purpurin has been the subject of various inquiries as to its biologic activity. It appears to have anti-angiogenesis activity [9], anti-mutagenic activity [10], anti-carcinogenic [11] and adjuvant activity [12], anti-inflammatory activity [13], anti-fungal activity [14], and anti-bacterial activity [15]. Purpurin's high antioxidant capacity may be responsible for many of its bioactivities [2]. Malik, et al. [16] reviewed the use of flavonoids and anthraquinones as oxidase inhibitors for medicinal applications. Oxidative stress is not only linked to the diseases associated with obesity and metabolic syndrome, but also with the hypertrophy and hyperplasia of adipocytes [17].

A decrease in the volume of adipose tissue can be achieved by various means via: negative energy balance; inhibition of proliferation of cells; increase in apoptosis of cells; inhibition of differentiation of pre-adipocytes to

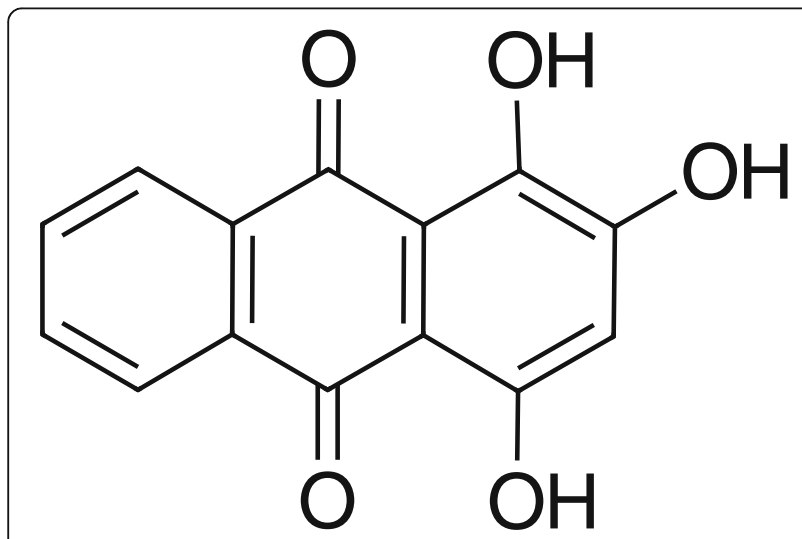

Fig. 1 Structure of purpurin adipocytes; inhibition of cellular lipid accumulation; and stimulation of lipolysis [18]. Polyphenols and other similarly antioxidative natural compounds have demonstrated anti-obesity effects by one or more of these processes [19, 20]. Of the anthraquinones, rhein [21] and emodin [22] have been shown to have antiadipogenic activity. Interestingly, in the above experiment with emodin, Yang, Yuan, Hao and Lu [22] found a concurrent increase in osteogenesis, supporting a possible link between the differentiation of the two cells lines, osteoblasts and adipocytes, which are both derived from mesenchymal stem cells. It is poignant that several evidence-based studies have tested anthraquinones against osteoporosis stemming from its traditional use to treat bone ailments in China, reviewed in An, et al. [23]. To our knowledge, purpurin has not been evaluated for any of these activities.

In vitro study of adipogenesis is most often accomplished using murine fibroblast 3T3-L1 cells. This cell line, first developed in 1974 [24], can be stimulated to differentiate into adipocyte-like cells under prescribed conditions. Relevant to this study, the model has been used extensively to study effects of natural substances on adipose cells [25]. In addition to microscopic examination, signaling molecules, transcription factors, and kinases can be monitored to assess adipogenesis [18].

The current study here has two major objectives: to apply purpurin to an in vitro adipogenesis assay, measuring the common biomarkers associated with the process, and to confirm the expected reduction in weight gain and expression of obesity-associated biomarkers in a mouse assay in which mice were fed a high-fat diet supplemented with purpurin.

\section{Methods \\ Materials}

Dulbecco's modified Eagle's medium (DMEM), phosphatebuffered saline (PBS), bovine calf serum (BCS), fetal bovine serum (FBS), and other miscellaneous cell culture reagents were purchased from Hyclone Laboratories (Logan, UT, USA). Purpurin, 3-isobutyl-1-methylxanthine (IBMX, aka MIX), dexamethasone (DEX), insulin, 2,7-dichlorofluorescein diacetate (DCF-DA), JC-1, and 3-(4,5-dimethylthiazol2-yl)-2,5-diphenyl tetrazolium bromide (MTT) were the products of Sigma-Aldrich (St. Louis, MO, USA). All reagents of analytical grade were purchased from SigmaAldrich and used without further purification and modification. MDI (MIX-DEX-Insulin)-differentiation medium consisted of DMEM containing 10\% FBS, $0.5 \mathrm{mM}$ IBMX, $1 \mu \mathrm{M}$ dexamethasone, $1 \mu \mathrm{g} / \mathrm{mL}$ insulin, $100 \mathrm{U} / \mathrm{mL}$ penicillin, and $100 \mu \mathrm{g} / \mathrm{mL}$ streptomycin. 3T3-L1 murine preadipocyte cells purchased from the American Type Tissue Culture Collection (Manassas, VA, USA). 


\begin{tabular}{|l} 
Treatment \\
Fig. 2 Scheme of 3T3-L1 pre-adipocyte differentiation and purpurin treatment
\end{tabular}

\section{Cytotoxicity of purpurin}

Cell viability was assessed using the MTT staining assay following the method of Mosmann [26]. This method has previously been applied to 3T3-L1 cells $[27,28]$. Briefly, cells were treated with serial concentrations of purpurin $(0,1,10,50,100,250 \mu \mathrm{M})$ for $24 \mathrm{~h}$ or $48 \mathrm{~h}$ at $37^{\circ} \mathrm{C}$ in humidified air with $5 \% \mathrm{CO}_{2}$. After treatments, the cells were stained by adding MTT, and the absorbance read at 570 and $655 \mathrm{~nm}$.

\section{In vitro adipogenesis}

\section{Cell culture and induction of differentiation}

Cells were induced to differentiate according to methods used previously [27, 28]. Briefly, 3T3-L1 murine preadipocyte cells were stimulated to differentiate by culturing in MDI medium in the presence and absence of purpurin for 2 days. At this point cells were tested for early-stage differentiation biomarkers. The cells were then allowed to fully differentiate by culturing in DMEM for eight additional days [29]. Figure 2 shows the cell-culturing protocol.

\section{Assays of purpurin-treated cells in early-stage differentiation}

As described above, 3T3-L1 cells were cultured for $48 \mathrm{~h}$ in 6-well plates with nontoxic concentrations $50 \mu \mathrm{M}$ and $100 \mu \mathrm{M}$ purpurin in the presence of MDI medium to induce differentiation. Cells were detached using a cell scraper and transferred to $1.5 \mathrm{~mL}$ brown tube before being microcentrifuged at $13,000 \mathrm{rpm}$ for $5 \mathrm{~min}$. The pellet was assayed as described below.

Intracellular reactive oxygen species (ROS) and mitochondrial membrane potential (MMP) The intracellular ROS level was determined [30] simultaneously to MMP using fluorescence labeling with DCF$\mathrm{DA}$ and $\mathrm{JC}-1$, respectively. Following the addition of $20 \mu \mathrm{M}$ DCF-DA or $5 \mu \mathrm{M}$ JC- 1 to the pellet, incubation continued for $30 \mathrm{~min}$ in the dark at $37^{\circ} \mathrm{C}$, before washing twice with PBS. Labeled cells were resuspended in $200 \mu \mathrm{L}$ PBS and transferred to a 96-well black plate. The fluorescence was monitored using a fluorescence plate reader (model SpectraMax Gemini XS, Molecular Device, Sunnyvale, CA, USA). The excitation wavelength and emission wavelength, respectively, were as follows:
$485 \mathrm{~nm}$ and $535 \mathrm{~nm}$ for DCF-DA, $485 \mathrm{~nm}$ and $530 \mathrm{~nm}$ for JC-1 green fluorescence, and $550 \mathrm{~nm}$ and $600 \mathrm{~nm}$ for JC-1 red fluorescence. MMP was calculated by dividing the red fluorescence by the green fluorescence. The measured fluorescence is expressed as a percent of the control group.

Adenosine triphosphate (ATP) assay The intracellular ATP level was determined using StayBrite ${ }^{\text {Tx }}$ Highly Stable Luciferase/Luciferin Reagent (BioVision Inc., Milpitas, CA, USA). Cells were lysed with ATP lysis buffer (50 mM Tris-Cl, $150 \mathrm{mM} \mathrm{NaCl}, 10 \mathrm{mM} \mathrm{MgCl}$, and $1 \mathrm{mM}$ EDTA, $\mathrm{pH}$ 7.5) added to the pellet. After centrifugation, $200 \mu \mathrm{L}$ of supernatant was mixed with $10 \mu \mathrm{L}$ luciferase/luciferin reagent and $1 \mu \mathrm{L}$ DTT. The luminescence was measured using TD-20/20 ${ }^{\mathrm{n}}$ luminometer (Turner Biosystems, Sunnyvale, CA). The measured luminescence was quantified using a standard curve and normalized by the amount of DNA in the cells.

Western blot analysis for p-AMPK and AMPK AMPK, p-AMPK, and $\beta$-actin were determined by Western Blot according to our previous method [28]. Briefly, cells were lysed with RIPA to release cell proteins, which were quantitated according to the Bradford method

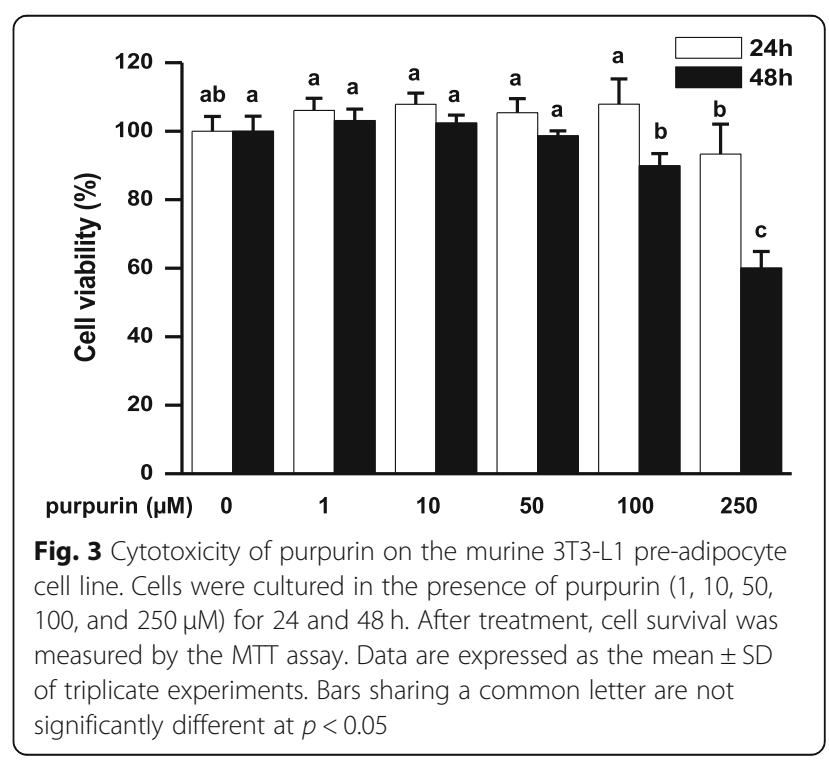



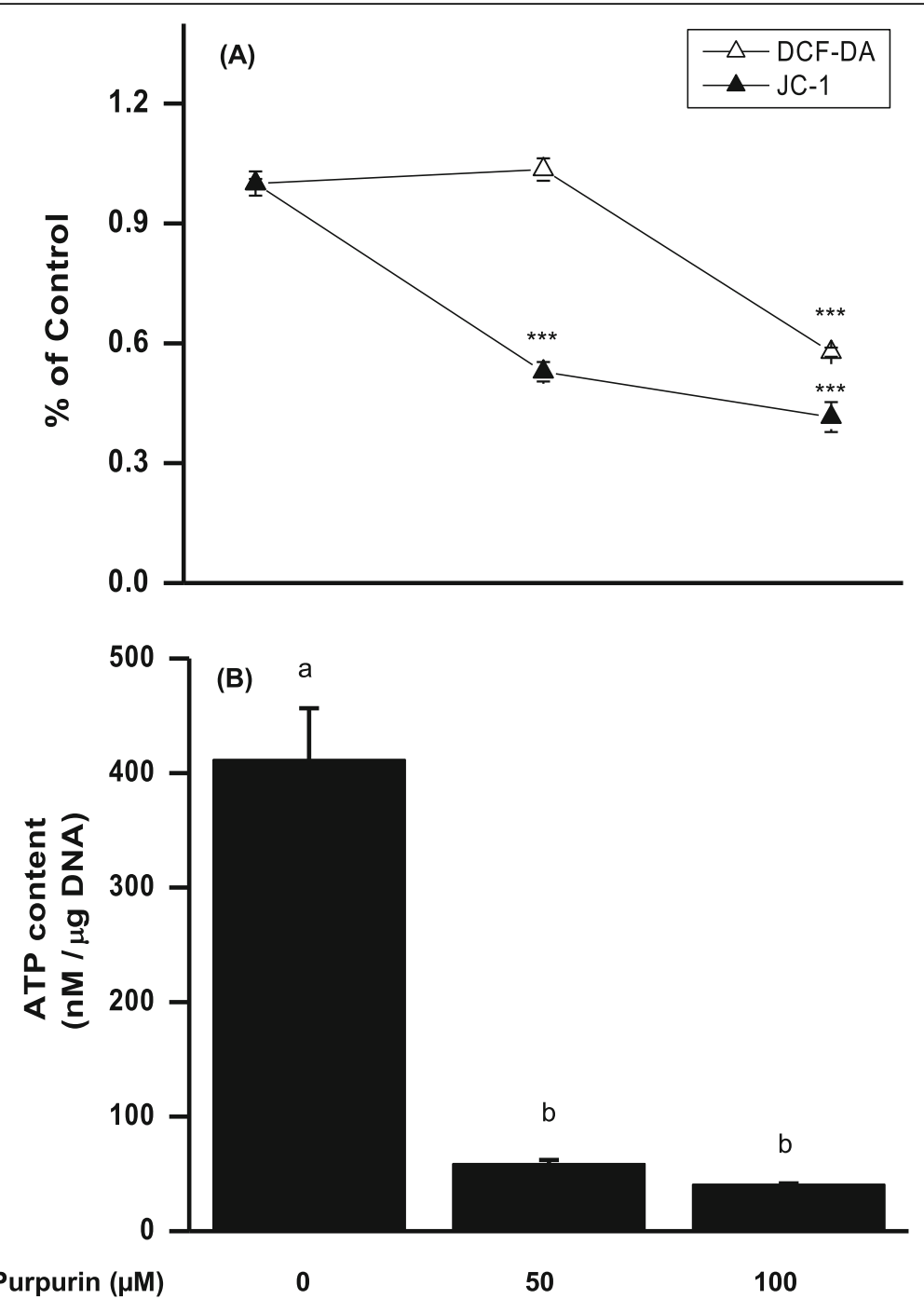

Fig. 4 Effects of purpurin on intracellular ROS levels, mitochondrial membrane potential, and intracellular ATP levels in 3T3-L1 cells treated with MDI for 48 h: a cells were labeled with DCF-DA for cellular ROS detection, and JC-1 for the detection of mitochondrial membrane potential; $\mathbf{b}$ cells were lysed, centrifuged and the supernatant mixed with luciferase/luciferin reagent, after which free ATP was detected with a luminometer. Data are expressed as the mean \pm SD of triplicate experiments. Bars sharing a common letter are not significantly different at $p<0.05$

(A)

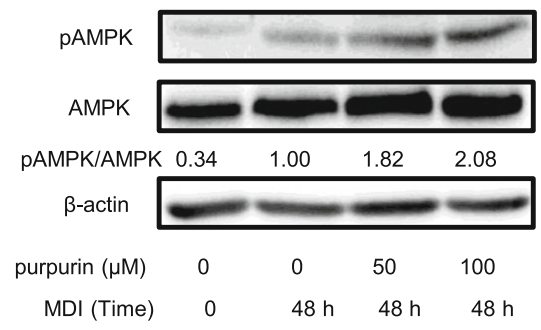

(B)

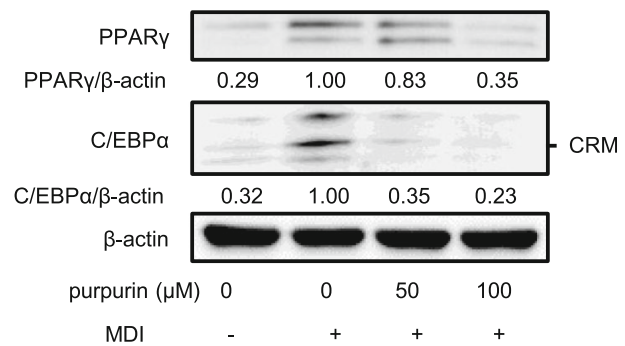

Fig. 5 Western Blot analysis of intracellular proteins from purpurin-treated cells in: a early-stage differentiation ( $2 \mathrm{~d}$ after MDI inducement), and $\mathbf{b}$ late-stage differentiation ( $8 \mathrm{~d}$ after MDI inducement). Cells were treated for the first $48 \mathrm{~h}$ with MDI and purpurin, after which these substances were removed from the culture. Figures represent results from at least three individual experiments. AMPK activity was expressed as the ratio phosphorylated to non-phosphorylated AMPK. Protein expression was calculated relative to $\beta$-actin, a constitutively expressed cellular protein 
(A)
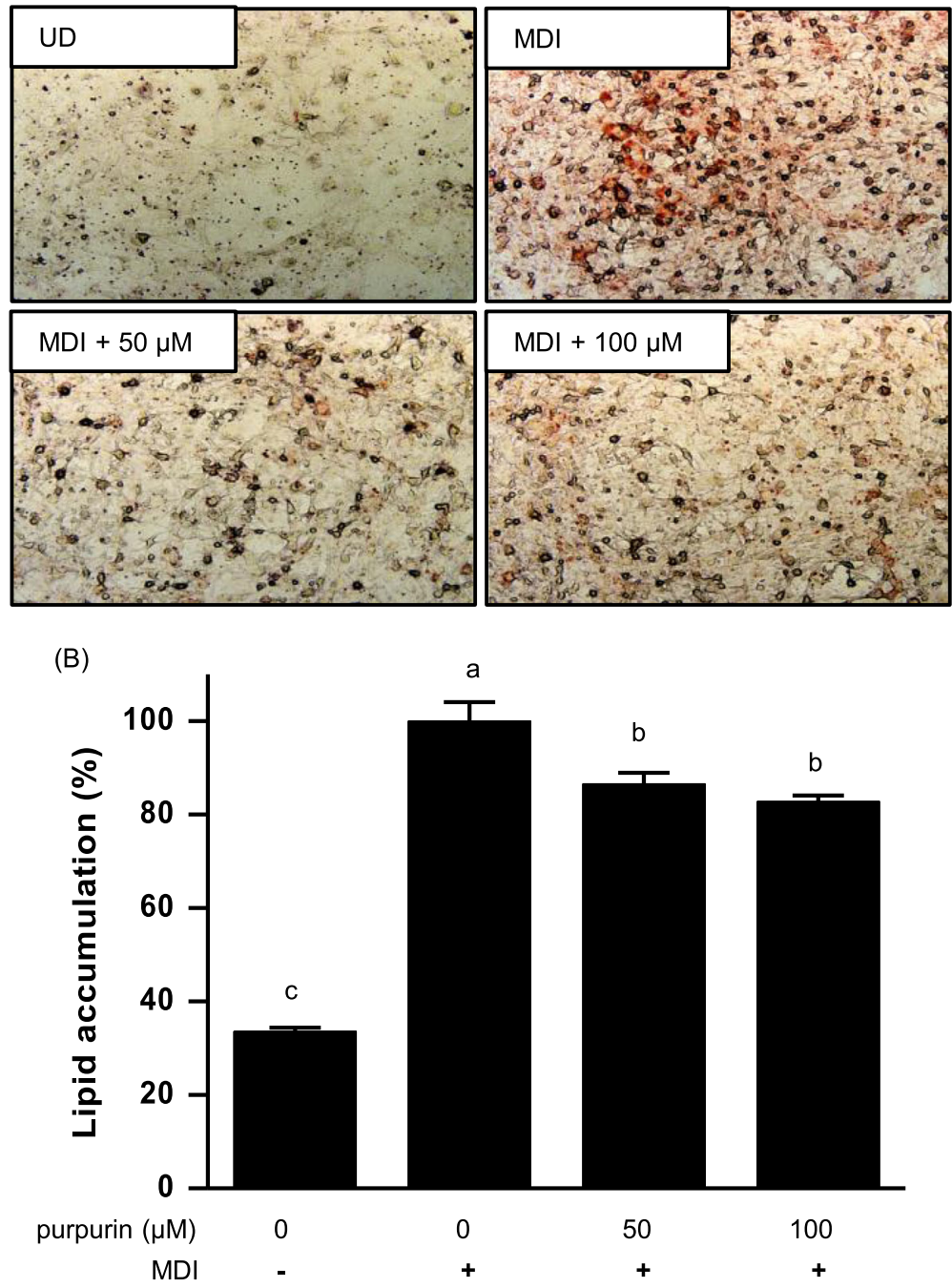

Fig. 6 Effect of purpurin on lipid accumulation in differentiated 3T3-L1 cells as measured with Oil Red O staining. The accumulation of lipid was evaluated: a microscopically; and (b) colorimetrically (absorbance at $520 \mathrm{~nm}$ ) from solubilized fat droplets collected from the stained cells. Data are expressed as the mean \pm SD of triplicate experiments. Bars sharing a common letter are not significantly different at $p<0.05$

using a Bio-Rad (Hercules, CA) protein assay kit. The cell extracts $(30 \mu \mathrm{g})$ were then separated on $10 \%$ SDSpolyacrylamide gels and electrophoretically transferred onto nitrocellulose membrane (Millipore, Billerica, MA, USA). The membrane was blocked then probed with anti-phospho-AMPK rabbit polyclonal antibody and anti-AMPK rabbit polyclonal antibody (Cell Signaling Technology, Danvers, CA, USA); and anti- $\beta$-actin monoclonal antibody (Millipore, Billerica, MA, USA). The secondary antibody reaction was with HRP (horseradish peroxidase)-conjugated anti-IgG antibody under the same conditions. Blots were developed using the ECL detection kit (Pierce, Rockford, IL, USA), and quantified using a gel documentation system (Vilber Solo S, Vilber Lourmat, Paris, France).
Assays of purpurin-treated cells in late-stage differentiation After the initial $48 \mathrm{~h}$ of MDI treatment, cells were cultured in DMEM containing $10 \% \mathrm{FBS}, 1 \mu \mathrm{g} / \mathrm{mL}$ insulin, $100 \mathrm{U} /$ $\mathrm{mL}$ penicillin, and $100 \mu \mathrm{g} / \mathrm{mL}$ streptomycin (Fig. 2), with the media changed every 2 days. At day 6 post-MDI treatment, cells were tested for mid-stage transcription factors and proteins.

Western blot analysis for PPARy, C/EBPa, and $\beta$ actin PPAR $\gamma, \mathrm{C} / \mathrm{EBP} \alpha$, and $\beta$-actin were analyzed by Western blot by the same procedure as above on cells in mid-stage differentiation. The antibodies used were antiC/EBPa rabbit polyclonal antibody (Cell Signaling Technology), anti-PPAR $\gamma$ monoclonal antibody (Cell 
Signaling Technology), and anti- $\beta$-actin monoclonal antibody (Millipore, Billerica, MA, USA).

\section{Assays of purpurin-treated differentiated cells}

Cells were fully differentiated at day 8 post-MDI treatment. Cellular fat and protein accumulation were assessed by direct assay and by microscopic examination.

Oil red $O$ staining Morphological changes were assessed by the method of Oil Red $\mathrm{O}$ staining as done previously [28]. Briefly, cells were fixed with $4 \%$ paraformaldehyde in PBS at $4{ }^{\circ} \mathrm{C}$ for $24 \mathrm{~h}$, washed and dried, then stained with Oil Red $\mathrm{O}$ for $1 \mathrm{~h}$ in the dark. Visualization was by light microscopy (model D50, Olympus, Tokyo, Japan) and photography [31]. Lipid accumulation was quantified by solubilizing the stained lipid droplets with 2-propanol and reading the absorbance at $520 \mathrm{~nm}$.

Triglycerides Triglycerides were determined according to previous methods [28]. Briefly, cells were harvested with the use of accutase (Sigma-Aldrich). Total lipids were extracted using a commercial kit (Sigma-Aldrich). Triglyceride content was measured using a commercial enzymatic assay kit (Wako, Osaka, Japan) according to the manufacturer's instructions. Triglyceride content was reported relative to cellular protein, which was determined according to the Bradford method using a Bio-Rad Protein assay kit [32].

\section{In vivo feeding studies}

Feeding studies in mice were done according to a previous method [28]. Pathogen-free male C57BL/6 mice, 68 weeks old, were obtained from Orient Bio Inc. (Seoul, Republic of Korea). The mice were housed in groups of 5 in a stainless-steel cage under a $12 \mathrm{~h}$ light/dark cycle with a temperature range of $20-22^{\circ} \mathrm{C}$ and relative humidity of $50 \pm 10 \%$. Mice were fed the pelletized normal commercial chow diet (Cat. No.5 L79, Orient Bio.) and tap water ad libitum for 1 week after arrival for acclimation. After acclimation, mice were arbitrarily divided into the following four groups $(n=10)$ : standard diet $(\mathrm{SD})$, high-fat diet only (HFD), high-fat diet with $40 \mathrm{mg} / \mathrm{kg}$ purpurin (HFD 40), and high-fat diet with $80 \mathrm{mg} / \mathrm{kg}$ purpurin (HFD 80). Standard diet consisted of $14 \%$ fat, $21 \%$ protein, and 65\% carbohydrate. High-fat diet (D12492, Research Diet, New Brunswick, NJ, USA) consisted of $60 \%$ fat, $20 \%$ protein, and $20 \%$ carbohydrate; $6 \%$ of the fat came from soybean oil and 54\% from lard. Purpurin was administrated via the diet. The amount added was recalculated weekly based on mouse weights and food intake. A sufficient amount of food was fed to allow the mice to eat freely. Food efficiency ratio (FER) was

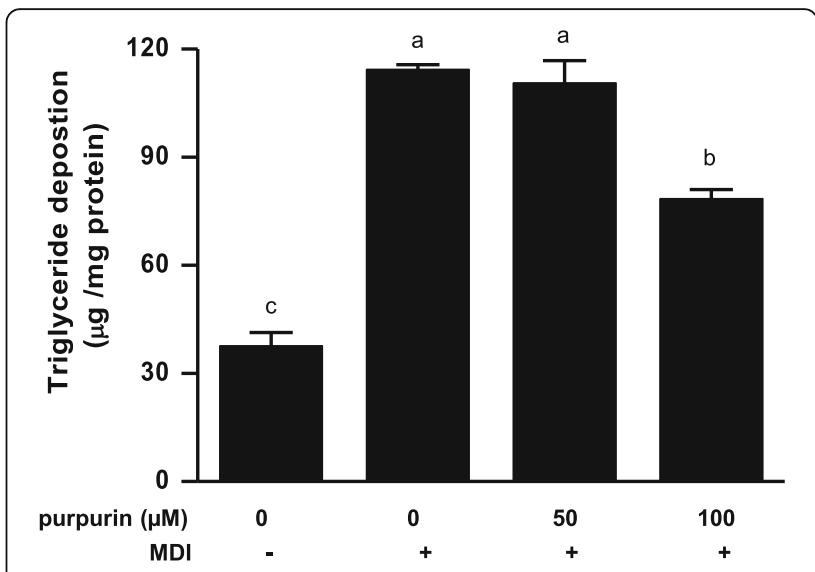

Fig. 7 Effect of purpurin on triglyceride deposition in fully differentiated 3T3-L1 cells. Data are expressed as the mean \pm SD of triplicate experiments. Bars sharing a common letter are not significantly different at $p<0.05$

calculated using the following formula; FER = body weight gain (g)/total food intake (g).

\section{Glucose tolerance test}

After 10 weeks, feed was withheld for more than $20 \mathrm{~h}$ before performing a glucose tolerance test. Fasting mice were orally administered $200 \mu \mathrm{L}$ of glucose at a dose of $1 \mathrm{~g} / \mathrm{kg}$ body weight. Blood was collected from the tail vein, and the blood glucose level was determined using an AccuChek Active Kit (Roche Diagnostics, Mannheim, Germany) at 0, 15, 30, 60, and $120 \mathrm{~min}$ after glucose challenge [33].

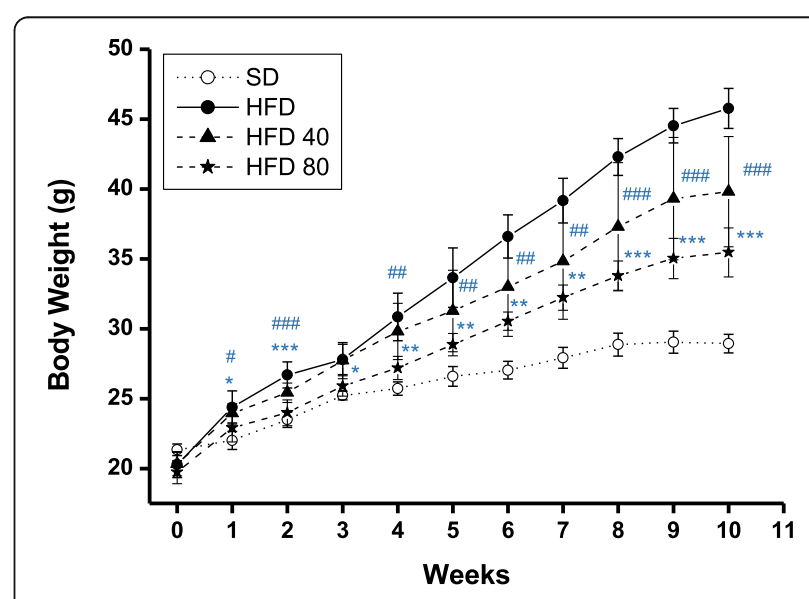

Fig. 8 Body weight changes of male C57BL/6 mice fed a high-fat diet only (HFD), $40 \mathrm{mg} / \mathrm{kg}$ purpurin-contained high fat diet (HFD 40), or $80 \mathrm{mg} / \mathrm{kg}$ purpurin-contained high fat diet (HFD 80) for 10 weeks. $\# p<0.5$, \#\# $p<0.01$, and \#\#\# $p<0.001$ on means of HFD 40 versus high-fat diet. ${ }^{*} p<0.5,{ }^{* *} p<0.01$, and ${ }^{* * *} p<0.001$ on means of HFD 80 versus high-fat diet 
Table 1 Effect of purpurin on weight gain, food uptake, and food efficiency ratio

\begin{tabular}{lllll}
\hline & Standard diet (SD) & High-fat diet (HFD) & HFD, 40 mg/kg purpurin & HFD, 80 mg/kg purpurin \\
\hline Weight gain (g/mouse) & 7.59 & 25.49 & 19.49 & 15.72 \\
Food uptake (g/day mouse) & $3.00 \pm 0.17^{\mathrm{a}}$ & $2.47 \pm 0.19^{\mathrm{b}}$ & $2.49 \pm 0.17^{\mathrm{b}}$ & $2.32 \pm 0.16^{\mathrm{c}}$ \\
Food efficiency ratio & 3.61 & 14.72 & 11.19 & 9.69
\end{tabular}

Data are expressed as the mean \pm SD of 10 mice experiments. Values sharing a common letter are not significantly different at $p<0.05$

\section{Analysis of biochemical indices in serum and histology of the adipose and liver tissues}

At the end of the experimental period, the mice were weighed, and then sacrificed by $\mathrm{CO}_{2}$ inhalation. After blood collection by cardiac puncture, the subcutaneous epididymal white adipose tissues and the liver were removed from the mice and weighed immediately. Blood samples rested at $4{ }^{\circ} \mathrm{C}$ for $30 \mathrm{~min}$ to induce blood clotting, and were then microcentrifuged at $3000 \mathrm{~g}$ for $30 \mathrm{~min}$ at $4{ }^{\circ} \mathrm{C}$. The resultant serum (supernatant) was stored at $-70^{\circ} \mathrm{C}$ until use. Serum triglyceride levels were quantitated following the method described above. Serum levels of total cholesterol were analyzed using a commercial kit (Asan Pharmaceuticals, Seoul, Korea) according to the manufacturer's instructions. Serum enzyme glutamate oxaloacetate transaminase/glutamate pyruvate transaminase (GOT/GPT) concentrations were determined using a colorimetric assay kit (Asan Pharmaceuticals) following the manufacturer's protocol. For histological analysis, the tissues were fixed with $4 \%$ paraformaldehyde in phosphate buffer $(0.5 \mathrm{M}, \mathrm{pH} 7.4)$, rinsed with water, dehydrated with ethanol, and embedded in paraffin. Then, the tissues were cut to a thickness of $4 \mu \mathrm{m}$ and mounted onto charged glass slides. The sections were dewaxed using xylene and ethanol, stained with hematoxylin and eosin $\mathrm{Y}(\mathrm{H} \& \mathrm{E})$, and assessed using light microscopy for the quantitation of adipocyte size and detection of fat accumulation lesions in the liver.

\section{Statistical analysis}

Results are expressed as the mean \pm SD of three independent experiments. Significant differences between means were determined by the one-way ANOVA test followed by Duncan's multiple range test using the Statistical Analysis Software package SAS (Cary, NC, USA). $p<0.05$ is regarded as significant.

\section{Results}

\section{Purpurin-induced effects in 3T3-L1 cells Cytotoxicity of purpurin}

To check for potential toxicity of purpurin on 3T3-L1 cells, viability after exposure to a series of concentrations of purpurin, and for 2 time periods, was determined using the MTT assay. The results showed (Fig. 3) that at the highest concentration tested, $250 \mu \mathrm{M}$, viability decreased only slightly and non-significantly at $24 \mathrm{~h}$, but by about $40 \%$ by $48 \mathrm{~h}$. The $100 \mu \mathrm{M}$ concentration showed no effect at $24 \mathrm{~h}$, and only about a $10 \%$ decrease at $48 \mathrm{~h}$. This concentration $(100 \mu \mathrm{M})$ was chosen as the maximum used for all further studies.

\section{Biomarkers in early-stage differentiation}

In order to meet the cellular energy and processing demands during lipid metabolism, normal adipogenesis is accompanied by an increase in mitochondrial biogenesis [34]. At $48 \mathrm{~h}$ post inducement, we tested standard measures of mitochondria activity: reactive oxygen species (ROS) levels; mitochondrial membrane potential (MMP); and ATP production. The results show that relative to the control, the purpurin treatment resulted in decreased levels of ROS generation with the $100 \mu \mathrm{M}$, but not with the lower $50 \mu \mathrm{M}$ dose. However, both mitochondrial membrane potential and ATP production were sharply curtailed with the lower $50 \mu \mathrm{M}$ dose, with an additional small drop with the higher $100 \mu \mathrm{M}$ dose (Fig. 4). These results show that adipogenesis-related mitochondrial biogenesis and/or activity was suppressed by the purpurin.

Expression and activation of proteins during differentiation The activation level of AMPK and the expression of PPAR $\gamma$ and $\mathrm{C} / \mathrm{EBP} \alpha$, critical proteins related to the differentiation of adipocyte, were verified through Western blotting analysis. The results showed that the activation

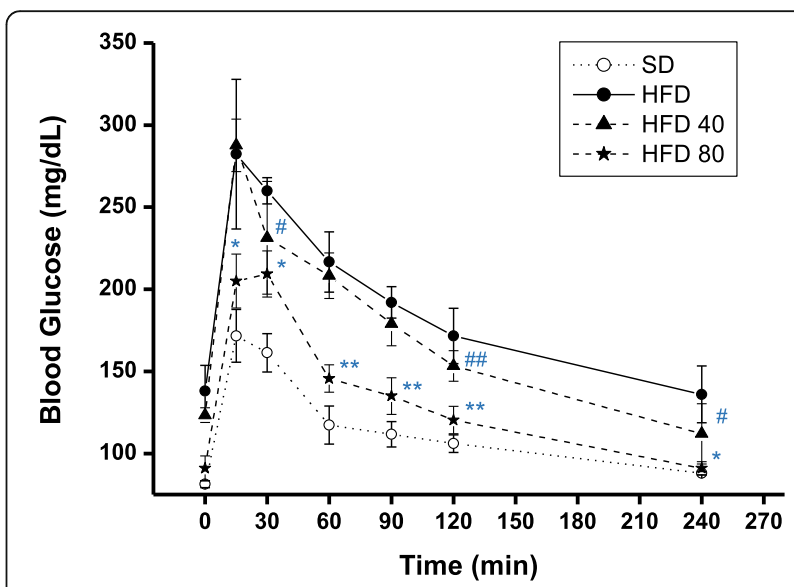

Fig. 9 Effect of purpurin on glucose tolerance in high-fat diet fed mice. \# $p<0.5$, \#\# $p<0.01$ on means of HFD 40 versus high-fat diet. ${ }^{*} p<0.5,{ }^{* *} p<0.01$ on means of HFD 80 versus high-fat diet 
Table 2 Effects of purpurin on plasma lipid profiles in high-fat fed mice

\begin{tabular}{lllll}
\hline & SD & HFD & HFD 40 & HFD 80 \\
\hline Glucose $(\mathrm{mg} / \mathrm{dL})$ & $85.2 \pm 7.9^{\mathrm{b}}$ & $147 \pm 18^{\mathrm{a}}$ & $132 \pm 17^{\mathrm{a}}$ & $99 \pm 13^{\mathrm{b}}$ \\
Total cholesterol $(\mathrm{mg} / \mathrm{dL})$ & $107.0 \pm 1.3^{\mathrm{d}}$ & $151.6 \pm 4.8^{\mathrm{a}}$ & $139.7 \pm 1.3^{\mathrm{b}}$ & $117.49 \pm 0.50^{\mathrm{c}}$ \\
Triglyceride $(\mathrm{mg} / \mathrm{dL})$ & $85.2 \pm 2.7^{\mathrm{c}}$ & $123 \pm 14^{\mathrm{a}}$ & $98.7 \pm 8.8^{\mathrm{b}}$ & $76.4 \pm 2.0^{\mathrm{c}}$ \\
\hline
\end{tabular}

Data are expressed as the mean \pm SD of 10 mice experiments. Values sharing a common letter are not significantly different at $p<0.05$.

of AMPK (production of phosphor-form) was increased by purpurin treatment (Fig. 5a), and the level of expression of PPAR $\gamma$ and C/EBP $\alpha$ was decreased by purpurin treatment in a dose-dependent manner (Fig. 5b).

\section{Lipid accumulation in fully differentiated cells}

At day 10 post-MDI administration, the control preadipocytes were fully differentiated to adipocytes. Lipid accumulation in the adipocytes was measured by Oil Red O staining. Microscopic examination of cells stained with Oil Red O showed that lipid accumulation was inhibited by purpurin in a dose-dependent manner (Fig. 6a). The results were quantified by measuring the absorbance of the solubilized stained lipid droplets at $520 \mathrm{~nm}$. The results showed (Fig. 6b) that treatment with purpurin at $50 \mu \mathrm{M}$ and $100 \mu \mathrm{M}$ resulted in significant reductions of lipid accumulation in the cells (13 and 17\%, respectively).

\section{Triglyceride deposition in adipocytes}

The inhibitory effect of purpurin on lipid accumulation was determined by measuring the triglyceride content of the differentiated adipocytes relative to their protein content. The result showed that there was no significant effect on triglyceride content for the $50 \mu \mathrm{M}$ purpurin treatment, but triglyceride deposition was inhibited by $31 \%$ with the $100 \mu \mathrm{M}$ purpurin concentration (Fig. 7).

\section{Effects of purpurin on mice consuming a high-fat diet} Obesity was induced in mice by feeding a high-fat diet (60\% fat), and the effect of purpurin was investigated by adding $40 \mathrm{mg} / \mathrm{kg}$ and $80 \mathrm{mg} / \mathrm{kg}$ of purpurin to the diet.

\section{Mouse body weights}

The effect of purpurin on weight gain in mice fed a high-fat diet (HFD) was evaluated. The weight gain of mice fed the HFD was about 3.4-fold higher than that of the normal control diet group at 10 weeks. Oral administration of purpurin at the $40 \mathrm{mg} / \mathrm{kg}$ and $80 \mathrm{mg} / \mathrm{kg}$ level to the HFD resulted in reduced weight gain by 34 and $55 \%$, respectively (Fig. 8, Table 1). In addition, the increased food efficiency ratio (FER) due to the high-fat diet, a 4 -fold increase, was inhibited 32 and $45 \%$ by purpurin administration at dose of $40 \mathrm{mg} / \mathrm{kg}$ and $80 \mathrm{mg} / \mathrm{kg}$, respectively, indicating that purpurin has the capacity to suppress weight gain due to ingestion of high fat level in a dose-dependent manner (Table 1).

\section{Glucose tolerance}

To test their response to a glucose challenge, the mice were fasted for more than $20 \mathrm{~h}$, then treated orally with $1 \mathrm{mg} / \mathrm{kg}$ of glucose. Blood glucose was measured every 30 min after oral administration. The glucose challenge time-response curves show the purpurin treated mice had intermediate responses relative to the HFD and standard diets (Fig. 9). Moreover, blood glucose levels for the $80 \mathrm{mg} / \mathrm{kg}$ purpurin group, measured at 15,30 , and 120 min post-glucose administration, showed significant differences from HFD mice.

\section{Plasma glucose and lipid levels}

Blood samples taken at the time of animal sacrifice were evaluated for glucose, cholesterol, and triglycerides. The values for the parameters in the treatment groups fell between the positive and negative control except for triglycerides in the HFD 80 group, which fell below the standard diet group (Table 2). The HFD caused 173, 142, and 144\% increases in blood glucose, cholesterol, and triglycerides levels, respectively. The 40 and $80 \mathrm{mg} / \mathrm{kg}$ purpurin treatments reduced blood glucose increases by 24 and $78 \%$, cholesterol increases by 27 and $76 \%$, and triglyceride increases by 64 and $123 \%$, respectively.

\section{Effect of purpurin on organ weights}

Table 3 shows that purpurin did not seem to significantly increase or decrease the weights of the heart, lung, and kidney mouse organs, showing that although exposure of the mice to dietary purpurin for 10 weeks induced reduced weight gain of the mice, the antiobesity effect did not result in the corresponding reduction in weights of individual mouse organs. These results might imply a lack of organ toxicity.

Table 3 Effect of purpurin on organ weights

\begin{tabular}{llll}
\hline & \multicolumn{4}{l}{ Organ weight $(\mathrm{g})$} \\
\cline { 2 - 4 } & Heart & Lung & Kidney \\
\hline Normal diet & $0.152 \pm 0.026$ & $0.171 \pm 0.015$ & $0.351 \pm 0.035$ \\
High-fat diet only (HFD) & $0.161 \pm 0.015$ & $0.180 \pm 0.019$ & $0.400 \pm 0.019$ \\
HFD $+40 \mathrm{mg} / \mathrm{kg}$ purpurin & $0.154 \pm 0.017$ & $0.183 \pm 0.029$ & $0.382 \pm 0.039$ \\
HFD $+80 \mathrm{mg} / \mathrm{kg}$ purpurin & $0.146 \pm 0.029$ & $0.178 \pm 0.021$ & $0.376 \pm 0.038$
\end{tabular}

Data are expressed as the mean \pm SD of 10 mice experiments. No significant differences between test groups at $p<0.05$ 
Table 4 Effect of purpurin on the liver

\begin{tabular}{lllll}
\hline & SD & HFD & HFD 40 & HFD 80 \\
\hline Liver weight (g) & $1.05 \pm 0.08^{\mathrm{c}}$ & $1.57 \pm 0.08^{\mathrm{a}}$ & $1.23 \pm 0.15^{\mathrm{b}}$ & $1.07 \pm 0.02^{\mathrm{c}}$ \\
Triglyceride (mg/liver) & $20.8 \pm 1.9^{\mathrm{d}}$ & $69.4 \pm 5.0^{\mathrm{a}}$ & $36.5 \pm 3.5^{\mathrm{b}}$ & $28.16 \pm 0.75^{\mathrm{c}}$ \\
Total cholesterol (mg/liver) & $2.86 \pm 0.18^{\mathrm{b}}$ & $7.25 \pm 0.93^{\mathrm{a}}$ & $3.80 \pm 0.42^{\mathrm{b}}$ & $3.00 \pm 0.11^{\mathrm{b}}$ \\
GOT (IU/mL) & $6.7 \pm 1.3^{\mathrm{c}}$ & $87.9 \pm 4.9^{\mathrm{a}}$ & $23.9 \pm 3.8^{\mathrm{b}}$ & $18.4 \pm 2.2^{\mathrm{b}}$ \\
GPT (IU/mL) & $11.7 \pm 2.0^{\mathrm{c}}$ & $85.5 \pm 2.8^{\mathrm{a}}$ & $31.3 \pm 2.6^{\mathrm{b}}$ & $25.8 \pm 2.1^{\mathrm{b}}$ \\
\hline
\end{tabular}

Data are expressed as the mean \pm SD of 10 mice experiments. Values sharing a common letter are not significantly different at $p<0.05$

\section{Hepatic lipid accumulation and liver injury}

Livers were examined for weight changes, cholesterol and triglyceride levels, and for expression of hepatic enzymes (Table 4). In mice consuming the high-fat diet the liver weights increased 1.5-fold. Administration of purpurin at 40 and $80 \mathrm{mg} / \mathrm{kg}$ inhibited this increase by 65 and 96\%, respectively. The triglyceride levels of the livers were also reduced by the dietary purpurin in a dose-dependent manner. Both doses of purpurin reduced the HFD-induced cholesterol gain to baseline levels. To assess for possible liver damage induced by a fatty liver, expression of the liver enzymes glutamate oxaloacetate transaminase (GOT) and glutamate pyruvate transaminase (GPT) were measured. GOT and GPT increased 13- and 7-fold, respectively in the HFD animals. The increase in GOT was reduced by 79 and $86 \%$, and for GPT by 73 and $81 \%$, for the 40 and $80 \mathrm{mg} / \mathrm{kg}$ doses, respectively. These results demonstrate that dietary purpurin protected the liver against the adverse effects of a high-fat diet.

\section{White adipose tissue}

Changes in white adipose tissue resulting from the treatment with purpurin were evaluated (Table 5). HFD caused an increase in white adipose tissue weight (WAT), triglyceride levels, and adipose cell diameters by 5.0-, 10.5-, and 2.7-fold, respectively. The administration of $40 \mathrm{mg} /$ $\mathrm{kg}$ purpurin in the diet had no effect on WAT weight, but reduced HFD-induced increases of triglycerides by $13 \%$, and adipose cell diameters by $31 \%$. Eighty milligram per kiliogram purpurin in the diet reduced these increases by 38,59 , and $71 \%$, respectively.

\section{Histological change of liver and white adipose tissue}

Histological changes in liver and white adipose tissue were also evaluated. The administration of purpurin at
$40 \mathrm{mg} / \mathrm{kg}$ or $80 \mathrm{mg} / \mathrm{kg}$ resulted in the reduction of accumulated liver fat (Fig. 10a, red circle), as well as in the size of white adipose tissue cells (Fig. 10b, red square). The HFD caused the adipose tissue cell diameters to more than double, relative to the control. Approximate diameters were $300 \mu \mathrm{m}$ for control mice (SD), $800 \mu \mathrm{m}$ for mice on the HFD, $600 \mu \mathrm{m}$ for mice on the HFD40, and $500 \mu \mathrm{m}$ for mice on the HFD80 diets. These observations, taken together with the chemistry and biochemistry assays, indicate that purpurin decreased the hypertrophy (fat storage), as well as the hyperplasia (number) of the adipose cells.

\section{Discussion}

The animal studies showed that purpurin mitigated the negative effects of a HFD as evidenced by: (a) reduced weight gain; (b) increased glucose tolerance; (c) reduced plasma glucose, cholesterol, and triglycerides; (d) reduced fatty liver indicators, including liver weight, lipid and cholesterol accumulation, and liver enzymes (GOT and GPT); and (e) reduced white adipose tissue weight, adipose cell size, and adipose lipid accumulation. The food intake was unchanged for the $40 \mathrm{mg} / \mathrm{kg}$ purpurin group but decreased slightly (6\%) for the $80 \mathrm{mg} / \mathrm{kg}$ purpurin group, which could account for some of the changed indicators. Other organ weights were not affected by purpurin consumption, indicating non-toxicity.

The 3T3-L1 cell cytotoxicity assay showed that purpurin was not toxic at the concentrations used in this study for the cell assays: 50 and $100 \mu \mathrm{M}$. Zengin, Degirmenci, Alpsoy and Aktumsek [2] found neither purpurin nor alizarin was cytotoxic to L926 fibroblast cells. Ino, Tanaka, Okumura, Morishita, Makita, Mori, Kato and Nakamura [5] estimated the maximum tolerated oral dose in mice of the whole plant Rubia tinctorum, containing both anthraquinones purpurin and

Table 5 Effect of purpurin on white adipose tissue (WAT) weight, morphometry, and triglyceride contents

\begin{tabular}{lllll}
\hline & SD & HFD & HFD 40 & HFD 80 \\
\hline WAT weight $(g)$ & $0.40 \pm 0.07^{\mathrm{c}}$ & $2.03 \pm 0.21^{\mathrm{a}}$ & $2.00 \pm 0.54^{\mathrm{a}}$ & $1.41 \pm 0.46^{\mathrm{b}}$ \\
Triglyceride (mg/WAT) & $5.17 \pm 0.21^{\mathrm{d}}$ & $54.3 \pm 1.0^{\mathrm{a}}$ & $47.9 \pm 1.2^{\mathrm{b}}$ & $25.34 \pm 0.28^{\mathrm{c}}$ \\
Diameter of adipose cells $(\mu \mathrm{m})$ & $247 \pm 47^{\mathrm{d}}$ & $654 \pm 17^{\mathrm{a}}$ & $528 \pm 35^{\mathrm{b}}$ & $364 \pm 36^{\mathrm{c}}$ \\
\hline
\end{tabular}

Data are expressed as the mean \pm SD of 10 mice experiments. Values sharing a common letter are not significantly different at $p<0.05$ 


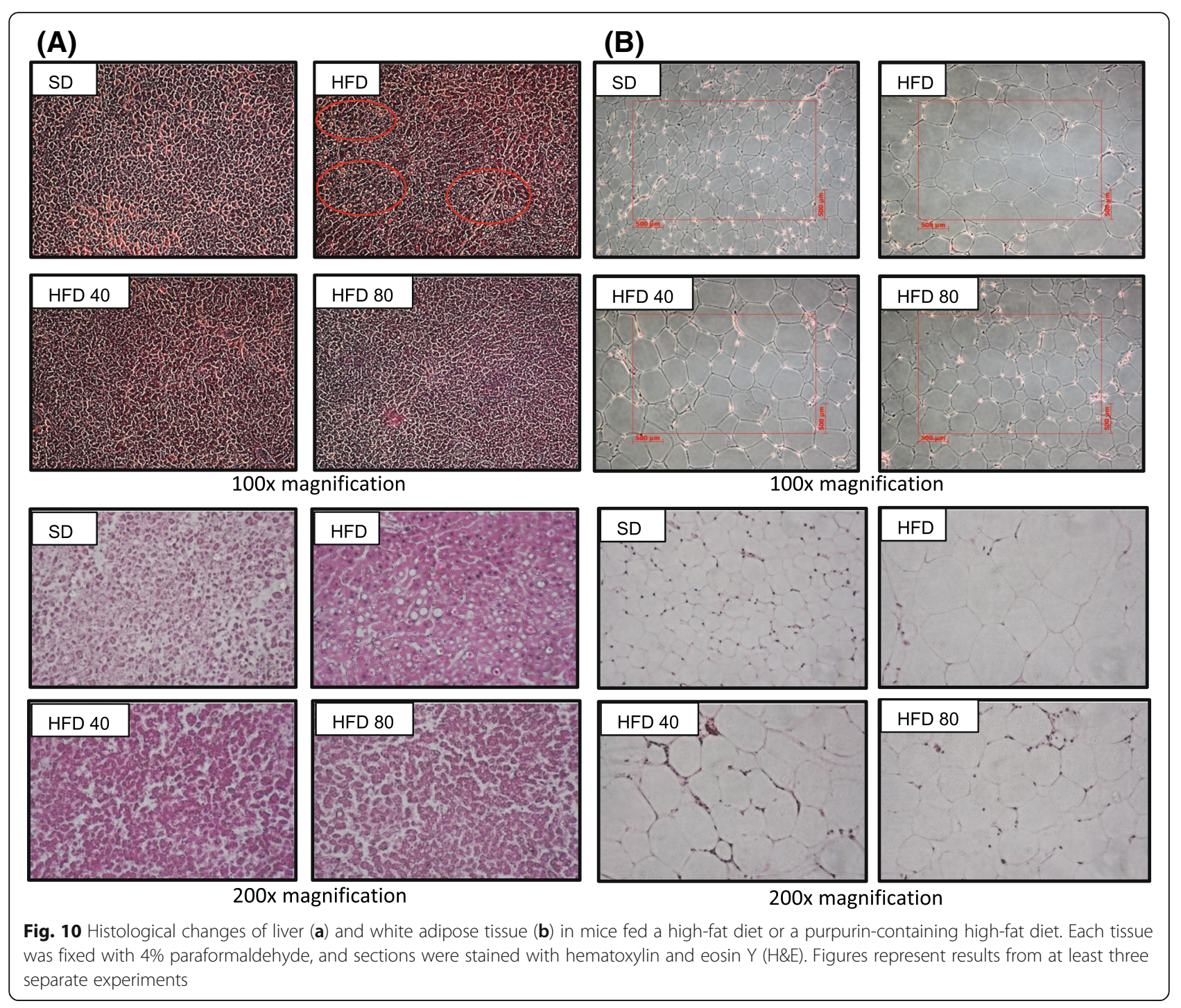

alizarin in glycosylated form, to be $3.5-5 \mathrm{~g} / \mathrm{kg}$ body weight. With Rubia tinctorum containing about $1 \%$ alizarin [35], this corresponds to about $35-50 \mathrm{mg} / \mathrm{kg}$ alizarin plus a smaller amount of purpurin; which is similar to the doses chosen in our oral feeding study of 40 and 80 $\mathrm{mg} / \mathrm{kg}$ body weight purpurin. The Ino, Tanaka, Okumura, Morishita, Makita, Mori, Kato and Nakamura [5] study found no clinical signs of toxicity nor weight loss in mice fed up to 5\% of their diet as Rubia tinctorum for 90 days. The lack of weight loss in their feeding study suggests that the weight loss in our study is related only to HFDinduced weight gain, and not to a failure to thrive.

Cell adipogenesis was apparently inhibited by purpurin by way of activation of AMPK (Fig. 5), an enzyme that modulates cellular energy homeostasis [36]. Purpurin treatment of 3T3-L1 cells at the $100 \mu \mathrm{M}$ level doubled the activation level of AMPK relative to the control at $48 \mathrm{~h}$. There are many possible drivers for activation of
AMPK, but the most common is a high AMP to ATP ratio [37]. AMPK is activated during a low energy states by sensing falling ATP levels, specifically high AMP/ ATP ratios within the cell [37]. The low ATP levels in the treated cells (Fig. 4) suggests that the purpurin mechanism is an AMP-dependent one [38]. A cellular energy regulator, pAMPK drives catabolic and minimizes anabolic processes in the cell as a means to return the cell to homeostasis [37]. Among other targets, pAMPK inhibits the transcription factors C/EBP $\alpha$ and PPARy [39], which are necessary for adipogenesis. Consistent with this dependence, we measured a decrease in C/EBP $\alpha$ and PPARY transcription in the 3T3-L1 cells, leading ultimately to a decrease in adipogenesis as evidenced by the fat accumulation in the cells at day 10 post-inducement.

Analysis of adipogenesis-induced changes in 3T3-L1 cells showed that purpurin sharply curtailed the increased mitochondrial activity/biogenesis normally observed during 
early-stage differentiation. Mitochondrial membrane potential, ATP production, and ROS generation were all lower in the $100 \mu \mathrm{M}$ purpurin-treated cells relative to the untreated cells (Fig. 4), but only the first 2 measures were lowered in the $50 \mu \mathrm{M}$ purpurin treatment. Because of ROS changes lagged behind the other measures, we hypothesize that ROS was reduced as a result of decreased mitochondrial activity. Increased mitochondrial biogenesis, including generation ROS and ATP production, is essential to the initiation of adipogenesis [34, 40]. It remains to be determined how purpurin acts on the mitochondria.

\section{Conclusions}

The investigation of the bioactivity of the anthraquinone purpurin has shown that purpurin has in vivo antiobesity and in vitro anti-adipogenic effects. Mice on a high-fat diet with added purpurin experienced a 55\% reduction in weight gain compared to those on the HFD control diet without added purpurin, and the effect was dose-dependent. In vitro, differentiation of 3T3-L1 cells was dose-dependently inhibited by purpurin, apparently by the activation of AMPK. It appears likely that AMPK activation was due to diminished ATP production from reduced mitochondrial biogenesis. Additional studies might elucidate the mechanism of the effect of purpurin on the mitochondria and determine the in vivo antioxidative capacity, as well as confirm the safety of the compound.

\section{Abbreviations}

AMPK: Adenosine 5'-monophosphate-activated protein kinase; C/ EBPa: CCAAT enhancer binding protein a; HFD: High-fat diet; MDI: MIX-DEXInsulin differentiation medium; MMP: Mitochondrial membrane potential; PPARY: Peroxisome proliferator activated receptor- $\gamma$; ROS: Reactive oxygen species

\section{Acknowledgements}

Not applicable.

\section{Authors' contributions}

WN, SHN, and SPK designed and carried out the experiments and prepared the tables, figures, and the experimental section. SHN and MF contributed to the design of the experiments and writing the first draft of the manuscript. $\mathrm{CL}$ analyzed the data and prepared the final draft of the manuscript. All authors approved the final manuscript.

\section{Authors' information}

Woo Nam and Dr. Sung Phil Kim are researchers at Ajou University. Dr. Seok Hyun Nam is a professor at Ajou University. Carol E. Levin is a researcher at Western Regional Research Center. Dr. Mendel Friedman is a senior scientist at Western Regional Research Center.

\section{Funding}

This research was partly supported by iPET (Korea Institute of Planning and Evaluation for Technology in Food, Agriculture, Forestry and Fisheries) High Value-added Food Technology Development Program (314076-3), and Technology Development Program (S2389154) of MSS (Ministry of SMEs and Startups). The funders played no role in the study design, execution, or reporting.

\section{Availability of data and materials}

The datasets used and/or analyzed during the current study are available from the corresponding author on reasonable request.

\section{Ethics approval and consent to participate}

The protocol for the mouse studies was approved by the Ethics Committee for Animal Care and Use, Ajou University, Suwon, Republic of Korea. All animal procedures were performed in compliance with institutional guidelines.

\section{Consent for publication \\ Not applicable.}

\section{Competing interests}

The authors declare that they have no competing interests.

\section{Author details}

${ }^{1}$ Department of Biological Science, Ajou University, Suwon 16499, Republic of Korea. ${ }^{2}$ Research Institute of Basic Science, Ajou University, Suwon 16499, Republic of Korea. ${ }^{3}$ STR Biotech Co., Ltd., Chuncheon 24232, Republic of Korea. ${ }^{4}$ Western Regional Research Center, Agricultural Research Service, U.S. Department of Agriculture, Albany, California 94710, USA.

Received: 23 September 2019 Accepted: 19 November 2019

Published online: 11 December 2019

\section{References}

1. Li Y, Jiang J-G. Health functions and structure-activity relationships of natural anthraquinones from plants. Food Funct. 2018;9(12):6063-80.

2. Zengin G, Degirmenci N, Alpsoy L, Aktumsek A. Evaluation of antioxidant, enzyme inhibition, and cytotoxic activity of three anthraquinones (alizarin, purpurin, and quinizarin). Hum Exp Toxicol. 2016;35(5):544-53.

3. Mouri C, Laursen R. Identification of anthraquinone markers for distinguishing Rubia species in madder-dyed textiles by HPLC. Microchim Acta. 2012;179(1-2):105-13.

4. Zhang X, Good I, Laursen R. Characterization of dyestuffs in ancient textiles from Xinjiang. J Archaeol Sci. 2008;35(4):1095-103.

5. Ino N, Tanaka T, Okumura A, Morishita Y, Makita H, Mori H, Kato Y, Nakamura M. Acute and subacute toxicity tests of madder root, natural colorant extracted from madder (Rubia tinctorium), in (C57BL/6 X C3H)F1 mice. Toxicol Ind Health. 1995;11(4):449-60.

6. Gong XP, Sun YY, Chen W, Guo X, Guan JK, Li DY, Du G. Anti-diarrheal and anti-inflammatory activities of aqueous extract of the aerial part of Rubia cordifolia. BMC Complement Altern Med. 2017;17(1):article number 20.

7. Quan MP, Tian CR. Hepatoprotective effect of essential oil of Rubia cordifolia. Modern Food Sci Technol. 2015;31(5):12-7.

8. Shen $C-H$, Liu C-T, Song $X-J$, Zeng $W-Y$, Lu X-Y, Zheng Z-L, Jie P, Zhan $R-T$, Ping $Y$. Evaluation of analgesic and anti-inflammatory activities of Rubia cordifolia L. by spectrum-effect relationships. J Chromatogr B. 2018;1090:73-80.

9. Park H, Shim JS, Kim BS, Jung HJ, Huh T-L, Kwon HJ. Purpurin inhibits adipocyte-derived leucine aminopeptidase and angiogenesis in a zebrafish model. Biochem Biophys Res Commun. 2014;450(1):561-7.

10. Marczylo T, Arimoto-Kobayashi S, Hayatsu H. Protection against Trp-P-2 mutagenicity by purpurin: mechanism of in vitro antimutagenesis. Mutagenesis. 2000;15(3):223-8.

11. Lajkó E, Bányai P, Zámbó Z, Kursinszki L, Szőke É, Kőhidai L. Targeted tumor therapy by Rubia tinctorum L.: analytical characterization of hydroxyanthraquinones and investigation of their selective cytotoxic, adhesion and migration modulator effects on melanoma cell lines (A2058 and HT168-M1). Cancer Cell Int. 2015;15(1):119.

12. Jeremić S, Amić A, Stanojević-Pirković M, Marković Z. Selected anthraquinones as potential free radical scavengers and P-glycoprotein inhibitors. Org Biomol Chem. 2018;16(11):1890-902.

13. Nam W, Kim SP, Nam S-H, Friedman M. Structure-antioxidative and antiinflammatory activity relationships of purpurin and related anthraquinones in chemical and cell assays. Molecules. 2017;22(2):265.

14. Tsang PW-K, Wong AP-K, Jung H-S, Fong W-P. Sub-MIC levels of purpurin inhibit membrane ATPase-mediated proton efflux activity in the human fungal pathogen Candida albicans. J Antibiot. 2014;67(4):349-50. 
15. Lee J-H, Kim Y-G, Yong Ryu S, Lee J. Calcium-chelating alizarin and other anthraquinones inhibit biofilm formation and the hemolytic activity of Staphylococcus aureus. Sci Rep. 2016;6:19267.

16. Malik N, Dhiman P, Sobarzo-Sanchez E, Khatkar A. Flavonoids and anthranquinones as xanthine oxidase and monoamine oxidase inhibitors: a new approach towards inflammation and oxidative stress. Curr Top Med Chem. 2018;18(25):2154-64

17. Furukawa S, Fujita T, Shimabukuro M, Iwaki M, Yamada Y, Nakajima Y, Nakayama O, Makishima M, Matsuda M, Shimomura I. Increased oxidative stress in obesity and its impact on metabolic syndrome. J Clin Invest. 2004; 114(12):1752-61.

18. Rayalam S, Della-Fera MA, Baile CA. Phytochemicals and regulation of the adipocyte life cycle. J Nutr Biochem. 2008;19(11):717-26.

19. Wang S, Moustaid-Moussa N, Chen L, Mo H, Shastri A, Su R, Bapat P, Kwun I, Shen C-L. Novel insights of dietary polyphenols and obesity. J Nutr Biochem. 2014;25(1):1-18.

20. Hsu C-L, Yen G-C. Phenolic compounds: evidence for inhibitory effects against obesity and their underlying molecular signaling mechanisms. Mol Nutr Food Res. 2008;52(1):53-61.

21. Liu Q, Zhang XL, Tao RY, Niu YJ, Chen XG, Tian JY, Ye F. Rhein, an inhibitor of adipocyte differentiation and adipogenesis. J Asian Nat Prod Res. 2011; 13(8):714-23.

22. Yang F, Yuan PW, Hao YQ, Lu ZM. Emodin enhances osteogenesis and inhibits adipogenesis. BMC Complement Altern Med. 2014;14:article number 74.

23. An J, Yang H, Zhang Q, Liu C, Zhao J, Zhang L, Chen B. Natural products for treatment of osteoporosis: the effects and mechanisms on promoting osteoblast-mediated bone formation. Life Sci. 2016;147:46-58.

24. Green $H$, Kehinde $O$. Sublines of mouse $3 T 3$ cells that accumulate lipid. Cell. 1974;1(3):113-6

25. Tung $\mathrm{Y}-\mathrm{C}, \mathrm{H}$ sieh $\mathrm{P}-\mathrm{H}$, Pan M-H, Ho C-T. Cellular models for the evaluation of the antiobesity effect of selected phytochemicals from food and herbs. J Food Drug Anal. 2017;25(1):100-10.

26. Mosmann T. Rapid colorimetric assay for cellular growth and survival: application to proliferation and cytotoxicity assays. J Immunol Methods. 1983;65(1-2):55-63.

27. Gwon SY, Ahn JY, Jung CH, Moon BK, Ha TY. Shikonin suppresses ERK 1/2 phosphorylation during the early stages of adipocyte differentiation in 3T3L1 cells. BMC Complement Altern Med. 2013;13(1):207.

28. Kim SP, Nam SH, Friedman M. Mechanism of the antiadipogenic-antiobesity effects of a rice hull smoke extract in 3T3-L1 preadipocyte cells and in mice on a high-fat diet. Food Funct. 2015;6(9):2939-48.

29. Zebisch $K$, Voigt $V$, Wabitsch $M$, Brandsch M. Protocol for effective differentiation of 3T3-L1 cells to adipocytes. Anal Biochem. 2012;425(1): 88-90.

30. Herranz-López M, Barrajón-Catalán E, Segura-Carretero A, Menéndez JA, Joven J, Micol V. Lemon verbena (Lippia citriodora) polyphenols alleviate obesity-related disturbances in hypertrophic adipocytes through AMPKdependent mechanisms. Phytomedicine. 2015;22(6):605-14.

31. Jiang D, Wang D, Zhuang X, Wang Z, Ni Y, Chen S, Sun F. Berberine increases adipose triglyceride lipase in 3T3-L1 adipocytes through the AMPK pathway. Lipids Health Dis. 2016;15(1):214.

32. Figarola JL, Rahbar S. Small-molecule coh-sr4 inhibits adipocyte differentiation via ampk activation. Int J Mol Med. 2013;31(5):1166-76.

33. Chen $G$, Han $Y$, He W, Liang F. Amentoflavone protects against high fatinduced metabolic dysfunction: possible role of the regulation of adipogenic differentiation. Int J Mol Med. 2016;38(6):1759-67.

34. Wilson-Fritch L, Burkart A, Bell G, Mendelson K, Leszyk J, Nicoloro S, Czech M, Corvera S. Mitochondrial biogenesis and remodeling during adipogenesis and in response to the insulin sensitizer rosiglitazone. Mol Cell Biol. 2003;23(3):1085-94

35. Goltz DM, Ahmadi S, Absalan G, Craig DB. Separation of historical dyes using capillary electrophoresis with laser-induced fluorescence detection. J Liq Chromatogr Relat Technol. 2012;35(14):2054-65.

36. Garcia D, Shaw RJ. AMPK: mechanisms of cellular energy sensing and restoration of metabolic balance. Mol Cell. 2017;66(6):789-800.

37. Hardie DG. Minireview: the AMP-activated protein kinase cascade: the key sensor of cellular energy status. Endocrinology. 2003;144(12):5179-83.

38. Hawley SA, Ross FA, Chevtzoff C, Green KA, Evans A, Fogarty S, Towler MC, Brown L, Ogunbayo OA, Evans AM, et al. Use of cells expressing gamma subunit variants to identify diverse mechanisms of AMPK activation. Cell Metab. 2010;11(6):554-65.
39. Habinowski SA, Witters LA. The effects of AICAR on adipocyte differentiation of 3T3-L1 cells. Biochem Biophys Res Commun. 2001; 286(5):852-6.

40. Zhang Y, Marsboom G, Toth PT, Rehman J. Mitochondrial respiration regulates adipogenic differentiation of human mesenchymal stem cells. PLoS One. 2013;8(10):e77077.

\section{Publisher's Note}

Springer Nature remains neutral with regard to jurisdictional claims in published maps and institutional affiliations.
Ready to submit your research? Choose BMC and benefit from:

- fast, convenient online submission

- thorough peer review by experienced researchers in your field

- rapid publication on acceptance

- support for research data, including large and complex data types

- gold Open Access which fosters wider collaboration and increased citations

- maximum visibility for your research: over $100 \mathrm{M}$ website views per year

At $\mathrm{BMC}$, research is always in progress.

Learn more biomedcentral.com/submissions 